7. Swanepoel

Departement Latyn

\title{
DIE MITES RONDOM DIE VAL VAN TROJE EN VERGILIUS SE UITBEELDING DAARVAN IN DIE TWEEDE BOEK VAN DIE AENE'ts *
}

\section{Inleidende perspektief}

\subsection{Oogmerk}

Die mites oor die val van Troje vertel ' $n$ aangrypende verhaal en in die tweede boek van die Aeneïs gee Vergilius op 'n besondere wyse gestalte daaraan. Maar Vergilius se vergestalting daarvan is slegs een van die variante van die verhaal. Die leser moet Christopher Marlowe se opmerking in gedagte hou:

"Many tales go of that city's fall, and scarcely do agree upon one point".

(In Grant 1973, p. 76).

Vanweë die eeuoue bekoring wat die Iliupersis of die val van Troje vir sowel storievertellers as toehoorders en lesers ingehou het, moet die Transvaalse Onderwysdepartement gelukgewens word met hul keuse van seleksies uit die tweede boek van die Aeneïs as voorgeskrewe werk vir matrikulante in 1982.

My oogmerk met hierdie voordrag is om sekere perspektiewe te bied op die mites rondom die val van Troje en die literêre vergestalting daarvan in die tweede boek van die Aeneïs. Dit is nie my oogmerk om die knap uiteensetting wat in die Tria Saecula se onderwysershandboek gegee is en waarin veral op verstegniese en stemmingselemente gekonsentreer word, hier te herhaal nie. My uiteensetting sal die mites aansny, maar my oogmerk is nie suiwer mitologies nie. Dit is 'n poging om. hoe sketsmatig ook al, aan te dui hoe aan die mitiese gegewe oor die val van Troje, soos aangebied in die tweede boek van Aeneïs. literère gestalte gegee is. Ek mik dus nie op 'n oorvertelling van die

- Lesing gelewer voor die Transvaalse tak van die Klassieke V'ereniging van Suid-Afrika te Potchefstroom op 19 September 1981. 
mites nie, maar probeer aantoon hoe hierdie mites deur Vergilius gebruik is in die opbou van die Aeneïs. In die literêre werk gaan dit nie om die inhoud as sodanig nie, maar om gestileerde inhoud (Elema, 1961, p. 41).

\subsection{Die Aeneis as simboliese mile}

Vergilius werk tussen die jare 29 en 19 v.C. aan die Aeneïs, myns insiens sy magnum opus, ' $n$ helde-epos in twaalf boeke. Die Aeneïs is ' $n$ multi-dimensionele gedig. Dit kan getipeer word as 'n verbeeldingryke fiksie (Johnson 1976, p. 2 en 22) of 'n poëtiese mite (Quinn 1968, p. 54). Quinn stel dit as volg: "... Virgil's narrative can be regarded as a Platonic myth, a story intelligible on a purely narrative level, but designed primarily to suggest intuitions of things, not easily put into ordinary words..." Hier kom die onderskeiding tussen die primêre (of mondelinge) epos en die sekondêre epos (geskrewe, maar bedoel om voorgelees te word) handig te pas. Die Aeneîs is 'n sekondêre epos; dit wil nie - en ek bedoel hierdie opmerking nie neerhalend of geringskattend ten opsigte van die primêre epos nie - net 'n aangrypende verhaal knap vertel nie, maar wil as ' $n$ simboliese fiksie in en deur die vertelling van die verhaal ook iets meer as net die verhaal vertel. Aeneas en sy volgelinge se sware stryd om, na hul vlug uit Troje, 'n nuwe tuiste vir hul gode en hulself te vind, is die mitiese vertrekpunt van 'n verhaal met simboliese implikasies wat nie net die legendariese Aeneas en sy' volgelinge raak nie, maar wat, soos Pöschl (1973, p. 23-24) in sy skitterende werk aangetoon het, ook kosmiese en historiese uitwysings vertoon.

Die mitiese gegewe is die vertrekpunt; dit verbind as intersimbool die kosmiese en di- historiese "vlakke" tot 'n eenheid.

Die basiese verhaalgegewe of tematiese "opperilaktestruktuur" van die Aeneïs, waardeur die simboliese uitwysing bewerkstellig word, is - "the heresy of paraphrase" ten spyt - as volg: Die Trojaanse prins Aeneas vlug met 'n groot aantal volgelinge uit sy gedoemde moederstad, Troje, met ' $n$ opdrag om vir sy' gode en mense 'n nuwe tuiste te vind en 'n volk te begin wat volgens goddelike beskikking bestem was om te heers en orde te bring.

Alhoewel hy 'n geroepene is, word hy in die vervulling van sy roeping teengestaan deur sekere gode (veral Juno), goddelike agente (Celaeno, Allecto, en andere), en mense (Dido en Turnus). Sy roepingsweg is 'n weg van lyding, van labor en casus, maar hy volhard daarin, sowel in sy omswerwinge op pad na Latium as in sy stryd teen diegene in Italië wat sy roepingsvervulling teenstaan. 
Ons het dus hier te make met grootse figure en belangrike gebeure, iets wat die epos as genre waardig is.

Dit dan die raamwerk waarbinne Vergilius die mites rondom die val van Troje gebruik. Laat ons vervolgens hierdie term "mite" van naderby bekyk; in besonder die eie-aardigheid van Romeinse mites.

\subsection{Die terme 'mite' en 'legende'}

Daar is in ons eeu, van die kant van sowel antropoloë, psigoloë, klassici en literatore ' $n$ besonder groot belangstelling in die mite. Hiermee gaan fyn onderskeidings oor wat 'n ware mite sou wees. hoe dit onderskei sou moet word van onegte mites, legendes, sagas, folk-lore, ensovoorts gepaard.

Die onderwerp wat vir die matrikulante aangegee is, is dan ook die legendes rondom die val van Troje.

Volgens die onderskeidinge hierbo, sou 'n mens ' $n$ mite kon beskryf as ' $n$ suiwer verbeeldingryke vertelling of fiksie, terwyl legendes eweneens fiktiewe verhale is. maar dan verhale met 'n historiese kern: dit wil sê verhale wat populêr as histories aanvaar is. Hierdie moderne teorieë oor wat 'n mite nou eintlik sou wees, werk dikwels beperkend deur, en dit sou - soos Michael Grant (1963, p. xix) aantoon - onmoontlik wees om die hele spektrum van die Griekse en Romeinse mitologie tuis te bring onder hierdie verengende definisies. Grant benadruk dan ook tereg die groot verskeidenheid van die Griekse en Romeinse mites.

In 'n poging om nie in ' $n$ terminologiese mynveld te beland of in haarklowery te verval nie. wil ek slegs daarop wi's dat die woord legende (>legenda) 'n Middeleeuse term is, wat aanvanklik gebruik is vir 'n verhaal oor ' $n$ heilige of Saint en wat in die erediens betrek is, Scott. 1965. p. 161. Eers later het dit die betekenis van 'n fiktiewe verhaal met 'n vermeende historiese kern verkry (Yelland, e.a., 1950, p. 125 . Grant 1973, p. 286, n. 27) wys daarop dat die Griekse en Latynse woordeskat in terminologiese onderskeiding tussen mites, folk-lore, ensovoorts tref nie. Om die rede is ek geneig om, soos Grant, nie die term "mite" te beperk tot "n suiwer verbeeldingryke fiksie nie, maar om ook verhale met 'n sogenaamde historiese kern daaronder in te sluit.

\subsection{Die kenmerke ran Romeinse mites}

Romeinse mites is in die verlede dikwels as in toevoegsel. en dan as in minderwaardige toevoegsel, tot die Griekse mitologie beskou. Grant het in 
sy werk, Roman myths (1973) die onhoudbaarheid van so 'n standpunt uitgewys. Afgesien van dic besliste aanleuning van Romeinse op Griekse mites, vertoon die Romeinse mites 'n eie-aard, wat in die bestudering van hierdie studieveld nog nie ten volle tot sy reg gekom het nie. Laat ons daarom kortliks die aandag vestig op die kenmerke van die mite, en die eie-aardigheid van die Romeinse mite toelig.

Die Romeinse mites verskil van die Griekse mites daarin dat dit nie spontaan uit die volk ontstaan het nie, maar dat dit in sy ont wikkeling gelei en gerig is deur intellektuele en oudheidkundiges wat tot die hoër stand en regeringsklas behoort het. Die Romeinse mites is dus in 'n sekere sin deur die hoër stand gefabriseer en die geslaagdheid van hierdie manipulasie blyk uit die feit dat hierdie verhale besonder gewild onder die gewone volk was.

Die Romeinse mites het dus weinig gemeen met die beperkende definisies i. at mense soos Otto Rank, Sigmund Freud en H.J. Rose aan 'n bloubloed mite opgelê het (kỵk Grant, 1973, p. 288, n. 48).

Die mites was $n$ gewilde onderwerp van bespreking in die Romeinse gemeenskap. Hul lewendige belangstelling in mites blyk uit die feit dat mites gedurig aangepas, verander en herstruktureer is ( $k y k$ Grant, 1973, p. xiii). Hieruit blyk dat die mite vir die Romein 'n sekere aktualiteit en eietydse relevansie gehad het.

Dit is nie moeilik om die oorsaak hiervoor aan te dui nie, want in die ontwikkeling vas die Romeinse mitologie het patriotiese. politieke en familiebelange 'n belangrike rol gespeel. Die groot aantal verskillende weergawes van die mites kan in 'n groot mate herlei word tot die onderlinge kompetisie tussen invloedryke families (kyk Grant, 1973, p. 252). In die Augustynse tydperk is verskillende mites hersien en dit is juis hierdie weergawes wat die volledigste aan latere tye oorgelewer is (kyk Grant, 1973, pp. 18-9, 238).

Die politieke. patriotiese en maatskaplike implikasies van Romeinse mites moet nie losgedink word van etiese oogmerke nie, aangesien hierdie dinge vir die Romein hand aan hand gegaan het. Vir " $n$ volk wat so ' $\mathrm{n}$ belangstelling in moraliteit gehad het as die Romein, was die mite 'n besonder geskikte middel vir die ondersoek en oordrag van morele waardes. Mitiese figure en hul optrede kan dus as exempla aan die hoorder of leser roorgehou word. Hier het ons te make met die didaktiese trek van die Romeinse mite. 
Om dit toe te pas op die Aeneïs: die epos kan onder andere gelees word as 'n fiksie van wat dit vir'n persoon en 'n volk inhou om geroepe te wees. Deur die konkrete uitbeelding van pius Aeneas sien ons ook 'n exemplum van en vir die latere Romein. En hiermee het ek nie gesê dat Aeneas bloot ' $n$ allegoriese figurant van die Romein is, soos wat Page (1960, p. xviii) te kenne wil gee nie.

Voorts was die Romeinse mite - soos talle ander mites - dikwels etiologies, met ander woorde dit wou die mitiese oorsaak of $\alpha_{\text {"it }}$ iov van 'n gebruik, instelling, toestand of gebeurtenis aantoon en verklaar (kyk Grant, 1973, p. $272,242)$. Die Aeneïs bied as epos in 'n sin seker die $\alpha$ tr Romeinse volk. Kyk byvoorbeeld die slotreël van die wyere prooemium van die Aeneïs: "tantae molis eral Romanam condere gentem" (Aen. 1,33).

Ons het hierbo aangetoon dat die verskillende variante van Romeinse mites ten nouste saamhang met familiebelange. Sover dit die Aeneïs aangaan, moet die belange van die gens lulia nie uit die oog verloor word nie, soos ons later aan die hand van die vlammeteken om die hoof van Iulus sal illustreer.

\section{5 . Wite en geskiedenis}

Die beeld wat gekonstrueer word van Rome se voor- en vroeë geskiedenis, kry ons gedeeltelik uit mitiese oorlewering, asook uit annalistiese geskrifte en argeologiese getuienis. Wat vir ons van belang is, is dat die mitiese oorlewering en die argeologiese getuienis in hoofsaak nie met mekaar klop nie, of dan slegs in 'n beperkte mate (kyk Grant, 1973, p. 1-19).

Bring hierdie feit die belangrikheid van die mites in gedrang? Soos Cary $(1970$, p. 45$)$ aantoon, moet die mites nie op sigwaarde aanvaar word nie, maar hy het ook reg as hy die belangrikheid van die mite vir ons verstaan van die Romeine uitwys. Grant (1973, p. 1) stel dit nog sterker. Hy beweer dat die mites van die Grieke en die Romeine net so belangrik as hul geskiedenis is vir ons insig in wat hierdie mense gedink en gevoel het.

Die Romeinse mites kan beskou word as "para-history". Die Romeinse mites moet nie gesien word as ' $n$ feitelike weergawe van die Romeine se voorgeskiedenis nie, maar as "what people, at different times said or believed had happened" (Grant, 1973, p. xvi). Dit toon dus aan ons hoe die Romein sy voorgeskiedenis ingeklee het, en juis uit hierdie inkleding of voorsteliingswyse kan ons veel leer van hoe die Romein homself, sy oorsprong en bestemming gesien het. 
Heinrich Schliemann se ontdekking van die historiese Troje is nog vars in ons geheue (k v.k Ceram, 1967, p. 44-57). Eeue lank is Troje "slegs" as 'n poëtiese fiksie beskou, maar Schliemann se ontdekking daarvan het die historiese kern van die mite blootgelê. Maar die opgrawing van Troje beteken natuurlik nie dat ons die hele Homeriese verhaal oor Troje, of sover dit ons aangaan - die Trojaanse herkoms van die Romeine heelhuids moet aanvaar nie. Die uitwerking van die verhale rondom die val van Troje toon wel aan hoe die skrywer/verteller se verbeeldingrykheid en vernuf ' $n$ aangrypende verhaal aan 'n vae historiese kern kon verknoop.

\subsection{Die Aeneïs as 'n hoofsaaklik mitiese (en nie-annalistiese) epos}

Vergilius se begeerte om 'n epos te skryf, is reeds in die sesde Ecloga en die derde boek ran die Georgica te kenne gegee. Toe hy uiteindelik sy nasionale epos geskryf het. het hy die Aeneas-mite as verhaalgegewe van 'n hoofsaaklik mit iese epos gebruik. Anders as Naevius (270-201/199 v.C.j en Ennius (239-169 v.C.) skryf hy nie sy epos in annalistiese styl nie.

Soos Bömer 1951.p. 11) opmerk, was sy keuse van mitiese epos gelukkig, en korrelter dit met al die groot eposse van die mensheid, wat na die mitiese voorgeskiedenis teruggryp.

Vergilius keer die orde van Naevius en Ennius om: waar hulle kort gedeeltes oor die Aeneas-mite gehad het, maar die hoofklem op die latere geskiedenis laat val het, doen V'ergilius net die omgekeerde. Sy hoofklem is op die mite, met kort vool litw'ysings na die "latere" Romeinse geskiedenis. Buchheit (1963, p. 14) nnem die Aeneïs 'n versmelting van die mitologies-homeriese en die histories enniaanse epos, wat tot 'n nuwe eenheid omskep is.

Die voordeel van 'n hootsaaklik mitiese epos is ooglopend, en kan met verwysing na tristoteles (II $\epsilon \iota \iota$ II $o \iota \eta \tau \iota \kappa \hat{\eta} s, 9$ ) verduidelik word. Aristoteles kontrasteer daarin geskiedskrywing en digkuns, en bevind dat poësie meer universeel as geskiedenis is. Waar geskiedskry wing liniêr van aard en dus sonder noodwendige strukturele eenheid is, is 'n literêre kunswerk organies van aard, dit wil sê al die konstituerende elemente daarvan word deur ' $n$ skrywer tot 'n organiese cenheid gebring. Die oorbodige word weggelaat. en slegs dit wat meewerk tot dic vergestalting van die sentrale tema word behou.

Die mitiese epos laat dus aan die skrywer $n$ vryer speel- of skryfruimtc. ('n hou nie die nadele van 'n historiese verknogtheid aan die feite in nie. Verder hou dic annalist iese aanbiedingswyse die gevaar in dat dit kan ontaard in $n$ prosaïese versifikasie van historiese gegewens. 
Van die vele motiverings wat aangevoer kan word oor waarom Vergilius juis op die Aeneas-mite besluit het (byvoorbeeld die ongeskikt heid van die Romulus-mite; die feit dat die Aeneas-mite 'n ou, ingeburgerde en patriotiese mite was, die feit dat die mite nog nie gefikseer was toe Vergilius daarmee in aanraking gekom het nie, ensovoorts), wil ek slegs drie oorwegings nader toelig.

Die deurslaggewende faktor was na alle waarskynlikheid die feit dat die Aeneas-mite aan Vergilius 'n aanknopingspunt met die wêreld van Homerus gebied het. Otis (1969, p. 29) stel dat Vergilius moes ingesien het dat Homerus "... was supreme - indeed indispensable as a source of symbols, a means of giving heroic connotation to contemporary reality".

Williams (1973, p. 12) wys verder daarop dat die digter deur middel van die Aeneas-mite die verlede en hede oor 'n tydperk van meer as 'n duisend jaar kon verbind.

Laastens was die Aeneas-mite reeds voor Vergilius dit as verhaalgegewe geneem het oor ' $\mathrm{n}$ lang tydperk met die gens lulia geassosieer (kyk Basson, 1975 , p. 21, n. 44) en hierdie assosiasie is in die Augustynse tyd deur Octavius-Augustus op die voorgrond gestel (kyk Quinn, 1968, p. 39).

\subsection{Vergilius en sy bronne vir die Aeneas-mite}

Die Aeneas-mite in sy verskillende variante, ook in die verbintenis daarvan met Rome, het sy aanleiding in die twintigste boek van Homerus se Ilias. Daar word Aeneas, wat in die llias as die vernaamste Trojaanse kryger na Hector beskryf word, deur Poseidon uit die hand van Achilles gered, en dan volg hierdie belangrike profesie oor hom:

En nou sal magtige Aeneas waarlik koning onder die Trojane wees, en ook sy seuns wat na hom gebore sal word (Homeros, Ilias XX, 307 en volgende).

Hierdie voorspelling het die verbeelding van menige latere skrywer aangegryp, veral wanneer dit handig te pas gekom het om op tipies Griekse w'yse aan ' $n$ belangrike stad ' $n$ mitiese stigter te gee.

Bömer (1951, p. 28) toon aan dat die teneas-mite reeds voor die literêre bewerkings daarvan in Etrurië bekend was, "n feit wat gestaaf word deur getuienis uit die beeldende kunste. Op die netelige vraagstuk hoc die gedagte ontstaan het dat Rome die dogterstad van Troje was, kan ek hier nie ingaan nie, maar die wat daarin belangstel. kan die verskillende teorieë in Bömer 1951, p. 23) gaan nalees. Bömer self beklemtoon die Etruskiese inv loed en 
stel dat die Acneas-saga in die Weste net vanuit Romeinse gesigspunt te verstaan is.

Dit is egter 'n feit dat die Homeriese eposse 'n geweldige invloed op latere skrywers uitgeoefen het (kyk Grant, 1963, p. 57-60).

Om Vergilius se verhouding tot sy bronne te probeer naspeur sal boekdele vul en hierdie voordrag is beslis nie die geleentheid daarvoor nie. In die verbygaan kan ons slegs daarop w'ys dat Vergilius sowel Griekse en Etruskiese as Romeinse bronne tot sy beskikking gehad het. Die werke van die Griekse skrtwers het in 'n groot mate verlore gegaan, die van die Etruskers (waarop ook Grant heelwat klem lê) in sy geheel, en ook die Romeinse bronne is erg fragmentaries.

Daarom sal ek nie - soos Bömer (1951, p. 12 dit stel - "die beinahe zu Tode gerittene Frage nach die Beziehung zu griechischen Vorbildern und dergleichen " hier probeer aanroer nie. In verband met Vergilius se aanleuning op Homeros kan Knauer (1964) geraadpleeg word.

Wat ek wel kortliks hier wil stel, is dat ons moet onthou dat Vergilius se hantering van die Aeneas-mite teruggaan op die werk van 'n magdom skrywers (kyk Grant. 1973, cpt. 2; Heinze, 1908; p. 238 en volgende). Verder wil ek aan die hand van Heinze (1908, p. 244) kortliks Vergilius se houding teenoor en hantering van die tradisionele oorleweringe tipeer. By die oorweging hiervan moet in gedagte gehou word dat oorspronklikheid in die poësie van die ('udheid glat nie die belangrike kriterium was wat dit vandag is nie. 'n Digter is nie gemeet aan die nuutheid van sy tema nie, maar aan die wyse waat op hy die bekende hanteer en daaraan vorm gegee het.

Vergillius se verhoudings tot sy bronne word as volg deur Heinze (1908, p. 24) gekenskets: Vergilius neem die tradisionele oorlewering nie ligtelik op nie en bly na daaraan. $\mathrm{Hy}$ kombineer motiewe uit verskillende outeurs. Waar die tradisie leemtes vertoon, vul hy dit ryelik aan. Hierdie mitiese byroeging vind plaas in aansluit ing by die tradisie in algemene vorm, maar nie in besonderhede nie. Vergilius veroorloof homself vryheid in die kombinering en herordening van die oorgelewerde en weerspreek die tradisie slegs wanneer dit vir sy doel uiters noodsaaklik is. Verder keur Vergilius die oorlewering ooreenkomstig sy eie oogmerk met die Aeneis (Heinze, 1908. p. 6 .

() In hierdie kort uiteensetting van 'n groot vraagstuk af te sluit, wil ek net die opmerking maak dat die V'ergilius-kritiek met betrekking tot die digter se' rerhouding tot sy bronne op twee wrses kan dwaal: eerstem tipien negen- 
tiende-eeus) deur ' $n$ allesoorheersende klem op Vergilius se aanhanklikhrid aan sy roorbeelde te plaas en blind te wees vir wat hy met die oorgelewerch gegewens maak: tweedens deur sy verhouding tot sy bronne weer te lig aan 10 slaan. Die volle implikasies van 'n Vergiliustoneel tref die leser dikwels eers in 'n vergelyking van Vergilius se werk met sy voorbeelde.

\section{Die mites rondom die val van Troje en Vergilius se uitbeelding daarvan in die tweede boek van die Aeneïs}

\subsection{Die Homeriese vertrekpunt}

Tcen hierdie agtergrond kan ons nou die mites of legendes rondom die val van Troje van naderby gaan bekyk en nagaan wat Vergilius in die tweede boek van die Aeneïs daarvan gemaak het.

lergilius se uitbeelding van die val van Troje vind kennelik aansluiting by Homerus se Ilias, maar heelhuids Homeries is dit nie.

Dit sien ons eerstens in die verskil in perspektief; die verteller se verskil in "vantage point". Want waar Homerus die stryd om Troje vanuit die hoek san die Griekse oorwinnaars benader, daar benader Vergilius dit uit die hoek van die Trojaanse oorwonnenes. En vanuit hierdie twee verskillende vogpunte word die val van Troje radikaal verskillend beleef en verhaal.

\subsection{Die oorsaak ian Troje se val. Die etiologiese faset}

\subsubsection{Die Homeriese weergawe}

Ons het vroëer opgemerk dat mites dikwels 'n etiologiese funksie het. Wat was die $\alpha$ t'T klem verskillend gelê word deur Homerus en Vergilius.

B! Homerus is die wegvoering van Helena die casus belli. In die Ilias word rertel hoe die Trojaanse prins, Paris, die seun van koning Priamus, op reis br die pale is van Menelaus, die koning van Sparta, aangedoen het. Paris word vriendelik deur Menelaus ontvang. maar toe die vriendelike gasheer s! oë uitvee, is Paris en Menelaus se pragtige vrou, Helena, op pad na Troje.

Maar die verontregte eggenoot het darem een troos: die eed war die Grickse rorste wat Helena die hof gemaak het aan haar vader, Tundareos, gesweer het. Omdat Helena so 'n uitnemende skone vrou was, het Tundareos ingresien dat daar maklik 'n stryd kon ontstaan tussen die verskillende Grick- 
se vorste wat om haar hand meegeding het, indien hulle hulle nie sou berus by die keuse van die man wat hy vir sy dogter maak nic. Daarom het hy, voordat hy sy keuse bekend gemaak het. al die vorste wat haar as vrou wou hê, laat sweer dat hulle die gelukkige man met alle mag sou beskerm as enigiemand sou probeer om Helena van hom af te neem.

Met die wegvoering va. Helena deur Paris het hierdie ced nou in werking getree; die Griekse vorste, onder aanvoering van Koning Agamemnon, die broer van Menelaus, ruk op teen Troje. Hulle probeer eers om Helena terug te eis deur ' $n$ gesantskap bestaande uit Menelaus en Odusseus na Troje te stuur, maar op 'n Trojaanse volksvergadering word hierdie eis geweier. Hierna breek die lange oorlog uit, met Helena as casus belli.

\subsubsection{Die weergau'e zan Vergilius}

Miskien sou iemand sê dat dit ook die verhaal is wat Vergilius vertel. En gedeeltelik sou hy reg hê, want Helena figureer ook in Vergilius se uitbeelding van die val van Troje. Maar die volle waarheid is dit nie. Vergilius gaan terug op ' $\mathrm{n}$ ander mite, wat nie aan Homerus bekend was nie. naam!ik die bekende verhaal van die twisappel. of eerder, op die ira lunonis wat die uitvloeisel hiervan was.

Die verhaal lui so. Op die huweliksfees van Peleus, die koning van Thessalië en Thet is, die seenimf, verskyn die ongenooide gas, Eris, die godin van twis, skielik tussen dit genooide gaste en gooi 'n goue appel met die inskripsie ("aan die mo، iste') tussen hulle in. Eers wou al die godinne die appel hê. maar uiteindelik onttrek almal behalwe Hera. Athena en Aphrodite hulle. Die drie vroue gaan na Zeus, maar - wyse god wat hy is - wil hy nie beslis oor die netelige vraag nie. Hy stuur hulle na Paris, die mooiste man en seun van koning Priamus van Troje. Terwyl Paris op die berg Ida is, verskyn die drie godinne glansryk aan hom en vra hom om die beslissing te fel. Elk belowe hom iets as hy haar as die mooiste sou aanwys: Hera beloof hom heerskappy oor alle mense; Athena weer roem in oorlog, maar Aphrodite, die godin van liefde, het die aanloklikste geskenk: sy belowe hom die mooiste vrou op aarde. Dit is dan ook in haar hand wat Paris die goue appel plaas (Conradie. 1964, p. 118 en volgende). Hierin lê die oorsaak van die wrok van Hera, of dan, in die Romeinse mitologie, van Juno. Wat Paris egter nie gewcet het nie, was dat die skoonste vrou op aarde reeds getroud was. Sy was Helena, die vrou van Menelaus. En hierna volg Paris se besoek aan Sparta en sy wegvoering van Helena na Troje.

Vergilius gaan nie in detail op hierdie verhaal in nie, maar in die prooemium san die eerste boek van die Aeneïs. word die ira lmouri be $\mathrm{kl}(\mathrm{cm}$ - 
toon, en word dit as die twééde rede van haar wrok teen die Trojane genoem. Aen I, 27,. Die vernaamste rede vir haar verset teen Aeneas en sy volgelinge. is solgens Vergilius se uitbeelding Juno se liefde vir Karthago en die feit dat sy gehoor het dat ' $n$ volk, ontspring uit Trojaanse bloed, eendag die Tiriese vestings omver sal werp (Aen I, 12-22).

Die leser van die Aene is weet ook dat, alhoewel Aeneas in die vervulling van sy roeping deur grootse figure soos Dido en Turnus teengestaan word, die eintlike teenspeler en antagonis van Aeneas niemand minder as die godin Juno, die aksiale figuur in die epos is nie.

Wanneer Aeneas dan ook, soos verhaal in die tweede boek van die Aeneïs, vir Helena wil doodmaak, dan keer sy godinmoeder Venus hom. Sy toon aan hom dat dit nie Helena is wat Troje ten gronde rig nie, maar die gode (Aen. 2.601-603). Sy maak Aeneas se oë ook dan daarvoor oop om te sien hoe Juno. Leptunus, Pallas en Juppiter self meewerk aan die vernietiging van Troje ten. 2, 604-623).

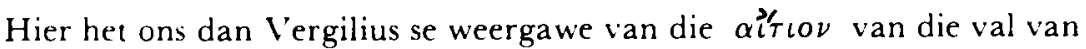
Troje, maar die val van Troje was op sy beurt weer in 'n bepaalde - minder direkte - sin die $\alpha^{\prime}(\tau \iota) \nu$ van die totstandkoming van Rome. Maar hieroor later meer.

\subsection{Die strukluur ian boek twee}

Laat ons nou, terwyl ons oorbeweeg na die verhale in boek twee, wat miskien minder algemeen bekend is, kortliks en met enkele pennestrepe die struktuur van die tweede boek van naderby bekyk. Dit sal sowel die nut hê om die verhaalgegewe van die tweede boek aan te stip, en - belangriker ons laat sien hoe Vergilius hierdie gegewens tot 'n eie struktuur orden.

Die tweede boek, wat 'n sterk dramatiese inslag vertoon, verloop in drie bewegings. ke wete (1) die verhaal van die houtperd, (2) die Nyktomachia of verhaal van die nagtelike stryd om Troje. en (3) die uitvlug van Aeneas.

Hierdie drie gedeeltes is van min of meer gely ke lengte; die vertelling oor die houtperd. waarin Sinon en Laocoon 'n belangrike rol speel, strek vanaf reël 13 tot 249. Hierdie gedeelte, wat dien as voorbereiding tot en verklaring van die val van troje. strek oor 236 versreëls. Die tweede gedeelte, wat volgens Quinn 1968. p. 119) die dramatiese hoogtepunt van die boek vorm, strek vanaf reël 250 tot 558 . Dit fungeer as die omraamde middelstuk van die boek. Die derde gedeelte, wat in terme van die res van die verloop van die verhaal. en in besonder vir die roepingsmolief besonder belangrik is, strek 
vanaf reël 559 tot 803 . L merk dus die min of meer simmetriese opbou van die boek.

Laat ons in meer detail daarna kyk, aan die hand van Quinn, 1968, p. 114-115) se analise met wie ek dit in hooftrekke eens is.

Inleiding

I. Die Houtperd

(i) Die inspektering van die perd

$40-56$

(ii) Laocoon $\mathrm{A}$

$57-198$

(iii) Sinon A B C

$199-233$

(iv) Laocoon B

234-249

(v) Toelating van die perd

Il. Die nag van Troje se val

(i) Die begin van die aanval

250-267

(ii) Hector se droomverskyning aan Aeneas

268-297

(iii) Aeneas-Panthus; Aeneas versamel 'n strydmag

298-369

Die Gevegte

(iv) In die strate

$370-401$

(v) B! die tempel van Pallas; Cassandra

$402-433$

(vi) Bu Priamus se paleis

434-505

(vii) Die dood van Priamus

$506-558$

(viii) Helena

$559-587$

(ix) Venus en die visie van die gode wat Troje vernietig

$588-633$

111. Die voorbereidings vir die uitvlug

(i) Anchises; die wondertekens van vlam en ster

634-704

(ii) Aeneas se geselskap wyk uit

$705 \cdot 729$

(iii) Creusa raak verlore; Aeneas se terugkeer

$730-770$

(iv) Die skimverskyning van Creusa

$771-794$

(v) Op die berg Ida

$795-804$

Heinze (1908. p. 1) maak tereg die opmerking dat Vergilius se grootsheid as kunstenaar veral te sien is in sy hantering en herstrukturering van bekende verhale. Met enkele uitsonderings het Vergilius tradisioneel oorgelewerde exempla vir die meeste tonele in die tweede boek gehad. Maar V'ergilius werk nie bloot eklekties nie, hy bied 'n nuwe "Gestait" aan die verhaal. Twee punte is in hierdie verband van besondere belang. In die eerste plek noet daarop gelet word dat Vergilius na die derdepersoonvertelling in die ecrste boek van die Aeneïs, in die tweede (en ook in die derde; oorslaan na die cerstepersonstertelling, voordat hy in die vierde boek weer terugkect na in 
derdepersoonsvertelling. Aeneas self vertel dus die verhaal van die val van Troje. Tweedens, en in noue samehang met die vorige punt word die hele verhaal opgebou rondom Aeneas as ooggetuie van die gebeure.

Hierdeur word ' $n$ besondere direktheid en dramatiese intensiteit aan die vertelling verleen.

Vergilius se vermoë as strukturalis kan veral gesien word in die simmetriese opbou van die verhaal van die houtperd. Die toneel begin met (i) die Trojane se inspektering van die perd; (ii) daarna lees ons van Laocoon se wantroue oor hierdie geskenk van die Grieke; (iii) daarna kom Sinon op die toneel, en sy vertelling is e veneens netjies georganiseer in drie gedeeltes, elk met sy eie klimaks; (iv) daarna volg die vernietiging van Laocoon en sy seuns, en (v) die toelating van die perd binne die stad. Skematies voorgestel kan die leser die georganiseerde omramende komposisie om 'n middelstuk merk:

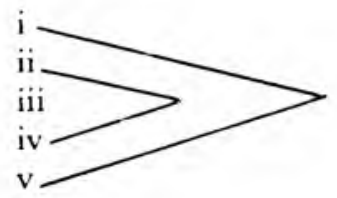

\subsection{Die houtperd can Troje}

Maar laat ons die fokus nou verskuif na die mitiese verhaalgegewe. Tereg stel Austin (1964, p. 36 ad Aen. 2, 15): "The Wooden Horse of Troy is one of the great imaginative conceptions of poetic myth".

Die verhaal van die houtperd word, asof die verhaal reeds goed bekend is, drie maal in die verbygaan in Homerus se Odusseia genoem (iv, 265 seq.; viii, 492f., ix, 523f.). Die verhaal is vollediger vertel in die llias Parra van Lesches, en in die lliuperis van Arctinus. Ook in die drama, Grieks sowel as Romeins (in verband met laasgenoemde dink ons veral aan Ennius se Equus Troianus), is die verhaal telkemale vertel. Vergilius se uiteensetting behou die eenvoud van die Homeriese uitbeelding (kyk Austin, 1964, ad. Aen. 2, 15). Sinon en Laocoon kom nie in Homerus se verhaal voor nie, en hier steun Vergilius op tradisionele oorlewerings van onder andere Quintus Smyrnaeus, maar met ingrypende omvorming; ook die opsomming van die verhaal wat deur Demodocus gegee is kyk Quinn, 1969, p. 115, n. 1 .

Hoe gebruik Vergilius hierdie twee figure? 
Die funksic vall Sinon en sy vertelling is om 'n oorsaak te bied vir waarom die Trojane wat hul stad tien lange jare met rasberadenheid en sukses verdedig het, uiteindelik deur die bedrog van een Griek (en deur hul eie stompsinnigheid, ironies genoeg voortvloeiend uit hul eie goedgesindheid) oorwin is. Sinon se vertellings is nie die hoogtepunt van logiese konsistensie nie, maar die manier waarop hy sy hoorders se goedgesindheid wen en uiteindelik - op die aanc'rang van die Trojane! - die betekenis van die perd vir hulle "verklaar" en 'n plan aan die hand doen oor wat met die perd gemaak moet word, is as oorredende vertelling meesterlik gedoen.

Die Laocoon-episodes omraam die vertelling ran Sinon. Laocoon verbeeld deur sy optrede die geregverdigde wantroue waarmee die Trojane die geskenk van dic Grieke moes bejeen. Dat Sinon juis op die toneel verskyn wannecr Laocoon die Trojane reeds byna oorreed het. getuig van goeie dramatiese aanvoeling. Dat Laocoon na die vertelling van Sinon deur die twee slange uit die see doodgemaak word. is $n$ klinkklare aanduiding dat nie net Sinon en die Trojane self vir hul ondergang verant woordelik is nie, maar dat die gode dic ondergang van Troje wil. Quinn 1969. p. 115) praat in dié verband tereg van die parallelisme tussen goddelike en menslike mot ivering vir die val van Troje.

Wat was Sinon se raad; sy "verklaring" van die geskenk aan Minerra? $\mathrm{Hy}$ vertel dat dit "n wygeskenk ter ere van die godin. as boetedoening vir die Grieke se verontheiliging van die Palladium. is. Hy vertel voorts dat indien die Trojane die geskenk sou skend, daar 'n geweldige vernietiging op Priamus en sy ry wag. maar dat, indien die Trojane die perd in hul stad sou insleep, die Trojane uiteindelik die stede van die Grieke sou vernietig (Aen. 2. 189-194).

I)aarom beshuit die 'Trojanc om die perd die stad binne te sleep. Die hele uitbeelding is ' $n$ toonbeeld van tragiek en is gelade met ironie. Ons verwys hier na die sogenaamde fala Troiana, voorspellings oor gebeure, waarvan die voltrekking die ondergang van Troje ingelui het. Hier dink 'n mens veral aan die diefstal van die Palladium deur L lysses en Diomedes. Die Palladium het as 'n soort magiese talisman, as beskermer san Troje gedien solank dit in die stad was $\mathrm{kyk}$ Austin. 1964, p. 83-85 ad Aen. 2. 163 vir die verskillende variante van die verhaal. (Ons keer weldra na die Palladium terug in verband met die tema van die kont inuiteit van Troje en Rome. Wat diefata Troiana betref, wil ons nog wys op Cassandra se roorspelling (Aen. 2. 246-247). Na Laocoon se dood besef net sy dat die perd Troje se ondergang sal reroorsaak: sy profeteer dit ook, maat die Trojane glo haar nie. Die whaal ran Cassandra lui so: Sy was die dogter van koning Priamus. In die Homeriese weergawe word sy nie in die hoedanigheid san profetes uitge- 
beeld nie. Die eerste oorlewering in die oorgelewerde literatuur is in Pyndaros en later in Aeschylos. Volgens die Aeschylos-weergawe het Apollo aan haar die gawe van profesie geskenk om haar liefde te wen. Toe sy hom verkul het, het hy hierdie gawe in 'n vervloeking verander, want alhoewel sy nog die toekoms reg kon voorspel, het niemand haar ooit geglo nie (kyk O.C.D., p. 210-211). Dit is by hierdie tradisie wat Vergilius aansluit. Ons het dus te make met skerp ironie, want afgesien van Cassandra se profesie, is daar nog Laocoon se amperse ontmaskering van die Grieke se oogmerk, die feit dat die perd in die stadspoort vasgesteek het, ensovoorts. Die ironie onderstreep die feit dat Troje se dae getel is. Fuit llium. Dit is deur die gode beskik.

\subsection{Troje, Priamus en Creusa}

Ons kan nie in die bestek van hierdie voordrag aan al die mitiese vertellings aandag gee nie. Voordat ek uitkom by die Troje-Rome-kontinuiteit, wil ek net kortliks verwys na twee figure waarvan die simboliek ten nouste saamhang met die simboliek van Troje. te wete Priamus en Creusa.

Priamus, die koning van Troje, 'n man wat vyfig seuns maar geen opvolger vir sy' troon gehad het nie, is 'n tragiese figuur. Alhoewel die verhaal oor Priamus algemeen bekend was, was Vergilius die eerste skrywer wat die val van Troje laat kulmineer het in Priamus se paleis en met die ou koning se dood (kyk Heinze, 1908, p. 40). Hy is die klassieke voorbeeld van 'n man wat die uiterstes ran geluk en ongeluk geken het. Sy belang in die Aeneïs is om te simboliseer da: - met si dood - die ou Troje verbigegaan het. Troje verteenwoordig dan ook in die epos. Aeneas se verlede.

Nou verwant hieraan is Creusa, die vrou van Aeneas. wat tydens sy en sy geselskap se uit tog uit Troje in die harwar van die vlug verlore geraak het. Aeneas storm terug om haar te soek. en sy verskyn in ' $n$ visioen aan hom. Oor haar boodskap aan Aeneas sal ons later iets sê. Hier wil ons net wys op die simboliek van Aeneas se drie maal vergeetse poging om haar gedaante te omhels (Aen. 2, i92-794). Hy kan Creusa nie op sy tog saamneem nie; ook sy' verteenwoordig soos Priamus en Troje die verlede.

\subsection{Die kontinuiteit zan Troje en Rome. Dic patriotiese jaset}

In die Aeneïs lees ons nie net "fuit Ilium" nie. maar ook "Troia nascens".

Ons het hierbo aangetoon dat een van die groot redes waarom V'ergilius die Aeneas-mite vir sy epos gebruik het. waarsk nnlik daarin geleë was dat hy 
met behulp daarvan die verlede en hede oor 'n tydperk van meer as 'n duisend jaar kon verbind. Laat ons hierdie stelling aan die hand van die mites in die tweede boek van Aeneïs illustreer.

Naby die begin van die tweede beweging van die boek, terwyl die Grieke besig is om hul aanslag op Troje te begin, verskyn Hector, bebloed en gewond, in 'n droom aan Aeneas (Aen. 2, 270 en volgende). Sonder om ag te slaan op Aeneas se vrde, gee Hector Aeneas opdrag om uit Troje te vlug. Hy sê aan Aeneas dat Troje sy "sacra" en "penatis" aan hom toevertrou; dat hy hulle as metgeselle met hom moet saamneem en vir hulle groot stadsmure moet oprig, nadat die see oorgesteek is. Hierdie opdrag word onmiddellik met Vesta en haar ewige vuur in verband gebring (kyk Aen. 2, 293-297).

Hier word Aeneas die eerste keer bewus gemaak van sy roeping. wat in die allernouste verband staan met die vind van 'n nuwe tuiste vir sy gode. Die noue verbintenis van die penates en lesta verdien vermelding k ky ook Aen. 5, 744; 11, $258 \mathrm{seq}$ ). Soos Austin (1964, p. 136-7 ad. Aen. 1. 196) opmerk, verteen woordig hierdie gode "the fundamental basis of Troy"s very being ... symbolized in full detail". Hier het ons te make met 'n etiologiese mite wat die kontinuiteit van Troje en Rome uitbeeld. Ten spyte van ander interpretasies stem ek met Austin (1964, p. 137 ad Aen. 2, 297) saam dat dit die staatsgode en die heilige vuur van Troje is wat hier bedoel word, en nie die huisgode van Anchises nie. In die uitvoering van sy roeping vervul Aeneas hierdie opdrag.

L.aat ons ons gedagtes nou verplaas van Troje na die historiese Rome. In die ronde tempel i an Vesta te Rome was daar'n heilige signum wat na bewering die werklike Palladium van Troje was. Die Romeine het geglo dat die reiligheid van Rome hierop berus het en Cicero (Scaur. 48: verwys daana as die "pignus nostrat salutis el imperi". Om die historisiteit hiervan verder te belig, kan daarop gew's word dat die tempel van Vesta in die jaar 241 v.C. in vlamme opgegaan het en dat hierdie signum deur die pontifex. $L$. Metellus, uit die vlamme gered is en dat die priester in die proses blind geword het. Die historisiteit van die Romeinse Palladum - atgesien van die oorsprong daarvan - word ook deur Ovidius in sy Fasti vi. 433 seq.) bevestig. Die godsdiensgeskiedskrywer, Kurt Latte, is van mening dat die Palladium beskou is as die tasbare simbool van die Penates ran Troje i $\mathrm{k}: \mathrm{k}$ Austin, 1964. p. 83-85 ad. Aen. 2, 163).

Ons weet dat Vesta as numen van vuur vir die Romein die simbool van Roma acterna was. Met die uitbeelding van die opdrag van Hector aan Aeneas bied Vergilius in die Aene is $n$ etiologiese fundering van die vermeende - en 
deur die Romein aanvaar as histories korrekte - kontinuiteit van Troje en Rome.

Op Cruttwell (1969, p. 27 en volgende) se teorie oor Vergilius se verbandlegging tussen Vesta en Cybele kan ons hier nie ingaan nie. By die afsluiting van sy bespreking oor Rome en Troje, maak hy egter die stelling dat die simboliek van die Aeneïs beweeg tussen twee pole, " $\ldots$ the one pole being a Troy whose symbols are Roman, the other pole a Rome whose symbols are Trojan..." (1969, p. 40).

Twee ander skimverskynings is ook hier ter sprake. As Venus na die beskry wing van die dood van Priamus aan Aeneas verskyn, dan ontsluier sy sy oë en hy kan sien hoe Neptunus, Juno, Pallas en selfs Juppiter meewerk aan die val van Troje (kyk Aen. 2,588 seq.). Aeneas verkry so uiteindelik die insig wat Hector reeds aan hom oorgedra het, naamlik dat Troje gedoem is. Daarna is hy bereid om uit die stad te vlug. As Creusa later in skimgedaante aan hom verskyn, dan deel sy hom mee dat sy soektog na haar tevergeefs is - in hierdie sin is die verlede dus verby - en dat hy sy reis moet voortsit na 'n verre land waar 'n gelukkige lot op hom wag. Die toekoms wink.

Die verbandlegging tussen Troje en Rome kan ook in die beelding en in die makro- of geheelstruktuur van die Aeneis aangetoon word. Eerstens, die beelding: Troje se val is 'n nagtelike val, maar as Aeneas en sy volgelinge uit die stad uit gevlug het, dan is die môrester, Lucifer, besig om oor die berg Ida op te gaan. Ons het hier te make met 'n beweging van donker na lig, van die verlede na die toekoms.

Wat die Troje-Rome-verhouding in die makro-struktuur van die Aenëis betref, die volgende: Dit is algemeen bekend dat die Aeneis 'n tweedelige struktuur vertoon: die eerste ses boeke verteenwoordig die Odusseiese Aeneis en vertel van Aeneas en sy volgelinge se omswerwinge op pad na Latium; die laaste ses boeke word die Iliadiese Aeneïs genoem. omclat dit vertel van Aeneas se stryd om Italië. Tussen die Odusse ̈ese en Iliadiese Aeneis is daar ' $n$ besliste tematiese verbandlegging aantoonbaar, ' $n$ verbandlegging wat struktureel verantwoord is. Ek verwys hier na wat 'n mens die "golf"- of (prosaïeser) die "sinkplaatstruktuur" van die Aeneis kan noem, in gevolge waarvan die epiese en meer dramatiese boeke in die epos mekaar afwissel. Ons kan dit skematies as volg voorstel: 


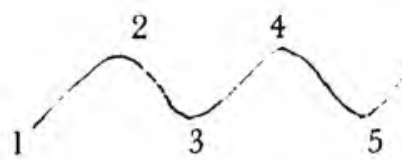

Troje
8

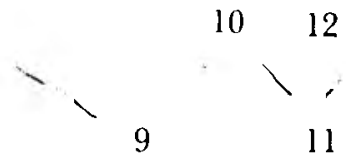

Pallanteum

Die tweede boek van die Odusseïese Aeneïs handel oor die val v'an Troje (die moederstad van Rome). In die tweede boek van die Iliadiese Aeneïs, dit wil sê boek agt, lê Aeneas besoek af aan Pallanteum, die stad van koning Evander, wat op die Palatynse heuwel geleě is, die presiese plek waar Rome later sou verrys. Dus: Troje verteenwoordig Aeneas se verlede; Pallanteum as oer-Rome sy en sy nakomelinge se toekoms.

Eintlik gaan hierdie verbandlegging nog verder terug. Dwarsdeur die Aeneis word Aeneas se afstamming uit die geslag van Dardanus beklemtoon. Dit is nie sonder rede nie, want daarmee wil V'ergilius sê dat Aeneas nie deel het aan die skuld van Troje nie. V'olgens 'n ou oorlewering wat hier deur Vergilius ont gin word, was Dardanus oorspronklik afkomstig uit Italië en het hy hom later in Troje gevestig. Aeneas, die Dardaniër, se uitvlug na Italië is die eintlik 'n terugkeer na sy "antiquam matrem" (kỵ . ten. 3, 96).

L' merk dat ons in die voorafgaande bespreking duidelik die etiologiese en patriotiese treki e van die Romeinse mite kan sien. Laat ons ten slotte wys op die politieke (dus patrioties in 'n enger, seksionele sin) en etiese trekke van die uitbeelding van die val van Troje in boek twee.

\subsection{Die etiese faset}

Sover dit die etiese faset van die verhaalgegewe in die tweede boek van die Aeneis aangaan, moet ek daarop wys dat die uitbeelding van Aeneas in hierdie boek nie in isolasie van die res van die Aeneïs beskou moet word nie. Onget wyfeld word Aeneas hier as 'n dapper held uitgebeeld. Aeneas se zirtus staan hier voorop. Ook sy vernaamste karaktertrek, sy pietas, word nie versw'yg nie. Dit sien ons veral in sy redding van Anchises uit die brandende stad. Maar aan insig in sy geroepenheid en die gehoorsaamheid wat dit verg, ontbreek dit Aeneas nog hier. Dit kan duidelik gesien word in sy tevergeefse, hoewel heroiese, verdediging van sy gedoemde stad nadat Hector in sy droomserskyning reeds duidelik aan Aeneas te kenne gegee het dat hy moet vlug en wir die gode van Troje 'n nuwe tuiste moet vind. 
Eers nadat Venus aan hom getoon het dat die gode Troje ten gronde rig, breek die insig vaagweg deur. En toe Anchises weier om Troje te verlaat, wil Aeneas weer tot die strydperk toetree. Die twee goddelike tekens (lulus se vlammende hoof en die ster) is nodig om hom daartoe te bring om Troje te verlaat. Maar soos Aeneas algaande 'n groter insig verwerf in wat sy geroepenheid inhou, so word sy pietas in die sin van getroue roepingvervulling sterker op die voorgrond geplaas. Aeneas word reeds hier aan die Romeinse leser as exemplum voorgehou, maar om die volle implikasie daarvan te besef, het die leser meer as net die tweede boek van die Aeneis nodig.

\subsection{Die politieke faset}

Die politieke trek van die Romeinse mite kan met groter duidelikheid aangetoon word. Wanneer Anchises weier om Troje te verlaat en liewer in die stad wil agterbly om te sterf, gebeur daar iets wonderliks wat hom van besluit laat verander. ' $n$ Vlam speel om die slape van Iulus, sonder om hom te skaad (kyk Aen. 2, 681-684). Anchises wat kort gelede nog verhaal het hoe Juppiter, die vader van die gode en koning van die mense, hom met bliksemstraal en vuur verskrompel het, (Aen. 2, 648-649) begryp onmiddellik dat dit 'n gunstige teken is en vra Juppiter om die teken te bevestig. Skaars het hy die versoek gerig, of' $n$ donderslag klink op en 'n ster, waarna verwys word as 'n sanctum sidus (Aen. 2, 700), verskiet. Nou is Anchises oortuig. Hy weet die gode waak oor Troje. Hy bid die gode om sy huis en nageslag te bewaar.

Die politieke en eietydse implikasie hiervan is ooglopend. Wanneer Anchises se weiering om te vertrek byna die ondergang van sỵ nakomelinge bewerkstellig, gryp die gode self in. Dat die vlam die hoof van die seun van Aeneas omhul, wat hier Iulus (en nie met sy ander naam, Ascanius) genoem word, het ' $n$ duidelike simboliese betekenis. Die vlammeteken toon aan dat die voortbestaan, of liewer die kontinuering, van Troje met die lot van Iulus verband hou. En Iulus sou later in Italië die stigter word van Alba Longa, die moederstad van Rome. Belangriker nog, dit is Iulus wat aan die magtige gens lulia sy naam sou gee. En hiertoe sou sowel Caesar as August us behoort. Die politieke implikasie hiervan sou geen Romein ontgaan het nie. Verder dien dit daartoe om die goddelike afstamming van die gens Iulia, waarop die Iuliërs hulle reeds sedert die tweede eeu v.C. beroem het, op die voorgrond te plaas. Want Iulus is die seun van Aeneas; Aeneas die seun van Venus, die "alma mater" van die Iuliërs en die Romeine.

V'erder sou die sanctum sidus, omdat dit hier onmiskenbaar in Iuliese konteks beskryf word, ook na alle waarskynlikheid by die Romeinse leser 'n eietydse 
assosiasie opgeroep het, te wete die van die sidus Iulium. Tydens die begrafnisspele wat Octavius, die latere Augustus, vir Julius Caesar gehou het, het ' $n$ komeet verskyn. Dit is algemeen geïnterpreteer as 'n aanduiding dat die siel van Caesar by die gode opgeneem is, en alhoewel Octavius in die openbaar voorgegee het dat hy hierdie interpretasie steun, lees ons in die werk van Plinius die Ouere (Naturalis Historia 2, 93) dat hy geglo het dat die ster vir hom en hy vir die ster gebore is. Die rol wat familiebelange in die opbou van die Romeinse mitologie gespeel het, word myns insiens deur hierdie twee voorbeelde geillustreer.

\subsection{Slotopmerking}

Ek het hierdie voordrag begin met die opmerking dat Vergilius in die tweede boek van die Aeneïs ' $n$ besondere gestalte aan die aangrypende verhaal oor die val van Troje gee. En hiermee wil ek ook afsluit. Wanneer hierdie boek met die matrikulante behandel word, moet die verhaal self op die voorgrond gestel word. Ek is oortuig daarvan dat dit die leerling se aandag sal boei, en ek vertrou dat die wyere raamwerk wat ek hier geskets het, sal bydra tot ' $\mathrm{n}$ diepere insig en genot by die lees van hierdie verhaal.

\section{LITERATUUR WAARNA VERWYS IS}

ALSTIN. R.G. red. 1964. P. V'ergili Maronis Aeneidos Liber Secundus. The Clarendon Press. Oxford.

BASSON. W.P. 1975. Pivotal Catalogues in the Aeneid. Adolf M. Hakkert. Amsterdam.

BÖMER. F. 1951. Rom und Troia; Untersuchungen zur Frühgeschichte Roms. Verlag für Kunst und Wissenschaft. Baden-Baden.

BLCHHEIT. Y. 1963. V'ergil über die Sendung Roms. Lneersuchungen zum Bellum Poenicum und zur Aeneis. Winter. Heidelberg.

C.AR Y. M. 1970. A History of Rome. Down to the Reign of Constantine. MacMillan. London. CER.AM. C.W. 1967. Gods, Graves \& Scholars. The story of Archaelogy: Transl. from the German by E.B. Garside and S. Wilkins. Penguin Books.

CONR.1DIF. P.J. 1964 Avonture van die Griekse Helde en Gode. Human \& Rousseau. Kaapstad, Pretoria.

CRLTWELL. R.W. 1969. Virgil's mind at work. An analysis of the Symbol ism of the Aeneid. Cooper Square Publishers. New York.

ELEM.A. J. 1961. Het kunstwerk in verband met zijn tijd. In Benaderingen van het literaire werk: zes belichtingen door J.H. Waszink e.a. Servire. Den Haag.

GR.A.T. M. 1963. Myths of the Grecks and the Romans. Weidenfeld \& Nicolson. London.

GRA.NT. M1 1973. Roman Myths. Pelican Books. Chaucer Press. Great Britain.

HEINZE. R. 1908 . Vergils epische Technik. Teubner. Leipzig. Berlin.

JOH.NSON. W.R. 1976. Darkness visible. A study of Vergil's Aeneid. Berkeley L'niversity Press. Californa.

K.NAER, G.X. 1964. Die Aeneis und Homer. Vandenhoeck \& Ruprecht. Göttingen.

O'TIS. B. 1970. The Originality of the Aeneid. In Dudley, D R. (red.) Virgil Routeledge \& Kegan Paul. London.

OXFORD CL.ASSICAL DICTIONARY. 1973. Clarendon Press. Oxtord. 
PAGE, T.E. (red.) 1960. The Aeneid of Virgil, Books I-VI. Mac Mlillan. London.

PÖSCHL, V. 1973. The Art of Vergil. Image and Symbol in the Aeneid. 'Transl. by G. Seligson. Ann Arbor Paperbacks. University of Michigan Press.

QUINN, K. 1968. Virgil's Aeneid. A Critical Desciption. Routeledge \& Kegan Paul. London. SCOTT, A.F 1965. Current literary terms. A concise dictionary of their origin and use. MacMillan. London.

Y"ELLAND, H.L. (e.a.) 1950. A handbook of literary terms. Angus and Robertson. Sydney. London. 